Journal of Education and Educational Development

$7(2), 328-350,2020$

DOI: http://dx.doi.org/10.22555/joeed.v7i2.199

\title{
Impact of Computer Integrated Technique in Science Education at Elementary Level: A Study in Karachi
}

\author{
Salman Ashiq \\ salman1ashiq@gmail.com \\ Saint Patrick's High school, Pakistan \\ Zehra Habib \\ zehra.habib@iobm.edu.pk \\ Institute of Business Management, Pakistan
}

\begin{abstract}
Computer technology plays an active role in the development of the economic, educational, and social growth of a country. Following a sequential explanatory mixed methods research design, the primary purpose of the study was to comprehend the advantages of teaching science to grade 6 students via Computer Integrated Teaching (CIT) as compared to the lecture-based approach. This study also investigated if computer integrated teaching enhanced students learning and contributed to higher achievement scores. The research was conducted for 6 months, with a focus on grade 6 science instruction. The quantitative part of the study comprised experimental research with a sample size of 62 students. Experimental group students were exposed to a strong intervention program of CIT, whereas the control group was taught by traditional methods. The findings of the study show that the experimental group scored significantly higher marks in science theory and practical tests than the control group students. The qualitative findings of the study, based on focus group interviews, support the quantitative findings as students favored technology-based learning because of its vast potential.
\end{abstract}

Keywords: computer integrated teaching (CIT), elementary level, information and communication technology (ICT) 


\section{Introduction}

Information and Communication Technology (ICT) in education is an umbrella term that includes all types of tools and techniques, which can be used for teaching and learning. The reason for the rapid diffusion of ICT throughout developed societies is because it is being widely used in homes and schools for enhancing the learning experience (Livingstone, 2012). Computer technology offers various techniques for improving teaching and learning and has gained popularity because it is considered a reliable source for delivering information to anyone, anywhere and at any time (Deaudelin \& Loiselle, 2006). Moreover, computer technology has also developed as an integral part of most of our businesses and organizations (Zhang \& Aikman 2007).

Computer integrated teaching (CIT) facilitates students to build knowledge and work in collaboration and supports learning in almost all subjects. However, it is most meaningful when used for teaching science because it offers different options and tools for real-time data logging (Newton, 2000). In addition, the benefits of using computer technology in science include access to updated and detailed information, which is both visual and auditory (Hogarth et al., 2006). Internationally, several research studies have been performed on the use of technology in science education which demonstrates how the incorporation of technological tools significantly helps students to improve their understanding of science concepts, compared to teaching via traditional methods.

In Pakistan, the quality of elementary education is not up to mark and students' academic performance is below standard (Annual Status of Education Report, 2013). According to the United Nations Global Education Monitoring Report, the standard of secondary education in Pakistan falls 60 years behind as compared to developed countries (Ali, 2018). Moreover, in the Pakistani education system, traditional teaching (lecture method) is a very common practice. Although it is the need of the hour to accelerate the use of technology, it is being used sparingly in the Pakistani education system. (Ahmed, 2016; Naqvi, 2020; Riaz, 2018; Riaz \& Houlgate, 2019).

\section{Purpose of the Study}

The core purpose of the study was to comprehend the benefits of using 
computer technology for teaching science to grade six students in contrast with the traditional approach of incessant lecturing in classrooms. This study investigated the effectiveness of computer-integrated teaching (CIT) for enhancing students learning possibilities, increasing interest in studies, and boosting achievement scores.

A related aim of this research study was to examine the variation in scores of grade six science students using computer integrated teaching and lecture-based teaching techniques. Furthermore, the current research aspired to comprehend the perceptions of students towards computer technology and their preferences regarding pedagogical strategies for learning science in school.

\section{Significance of the Research}

Computer integrated teaching helps in enhancing a constructive approach in the teaching and learning process as its effective use helps teachers to develop the interest of students for enhancing their research skills and enables them to cooperate through social groups, discovering new forms of interaction and communication (Tikam, 2016). Although it is possible to use computer technology for teaching most subjects, the focus of the current research was specifically on science because science is considered a core subject. Science is the most important subject taught in school due to its significance in students' daily life and global applicability to critical thinking and problem-solving skills (Hofstein et al., 2016). According to Harlen (2017), students learn how to develop their thought processes, tackle problems, and build the capability of making correct decisions based on the teachings of science.

\section{Research Questions}

1. What is the difference in the overall performance of grade 6 students in science tests (theory and practical) when taught by Computer-Integrated Teaching techniques and lecture-based teaching methods?

2. What are the learners' perceptions of Computer Integrated Teaching?

3. What are the preferences of students for learning in a classroom? 


\section{Hypotheses}

\section{Hypothesis 1}

There is a significant difference in the overall performance of grade six students in science tests when taught by computer integrated teaching techniques and when taught by a lecture-based teaching method.

\section{Hypothesis 2}

There is a significant difference in science theory test scores of students taught via CIT compared to students taught by the lecture-based method.

\section{Hypothesis 3}

There is a significant difference in science practical skills test scores of students taught by CIT and lecture-based teaching methods.

\section{Literature Review}

Schools need to do away with traditional methods of teaching that are unproductive and ineffective and teachers require gears for assisting, augmenting, and even altering classroom instruction (Parker et al., 2019). Instead of focusing on rote learning for science concepts, digital tools should be used to help students to share, compare, and evaluate data (Cauthers \& Cauthers, 2018). Western and eastern researchers to understand its advantages and to make it an effective way of delivering information have investigated the incorporation of computer technology in science education.

Park et al. (2009) conducted a quasi-experimental study in Korea to examine secondary school students' approach to science. They selected 234 middle school students, categorized them into five groups, and provided computer-assisted instruction (CAI) in science lessons. After the successful execution of CAI in the science classrooms for about two and a half months, findings of the study highlighted that CAI in science education showed a remarkable enhancement in their accomplishment and a robust change in students' perception toward science. Further, it provided evidence that computer-assisted instructions have the potential to benefit students who are weak in studies.

In a community college in Mississippi, Scott (2009) conducted a study to 
examine the differences between traditional and online science courses. The main purpose was to scrutinize the variance in students' achievement scores in online science courses as compared to students' achievement in traditional science sessions. She also investigated students' perceptions of the online courses as compared to courses delivered in the classroom in which 2,430 students participated. The research used aggregate data for students who had completed the online and traditional face to face lab science courses of 13 semesters. The findings showed that students performed better when computer technology was added to their course work. Moreover, the results showed clearly that $81 \%$ (more than three quarters) of students reported the quality of online instruction superior to traditional face to face teaching as compared to $19 \%$ (less than one quarter) who reported that traditional instruction was better than online teaching.

Khurshid et al., (2016), conducted a research study on learning physics at the secondary school level in Pakistan. The purpose of the study was to explore the benefits and issues related to the implementation of technology in science education at the secondary education level. Data collected from students clearly showed their preference for Information Communication Technology as being important for learning and understanding science.

\section{Figure 1}

\section{Conceptual Framework}

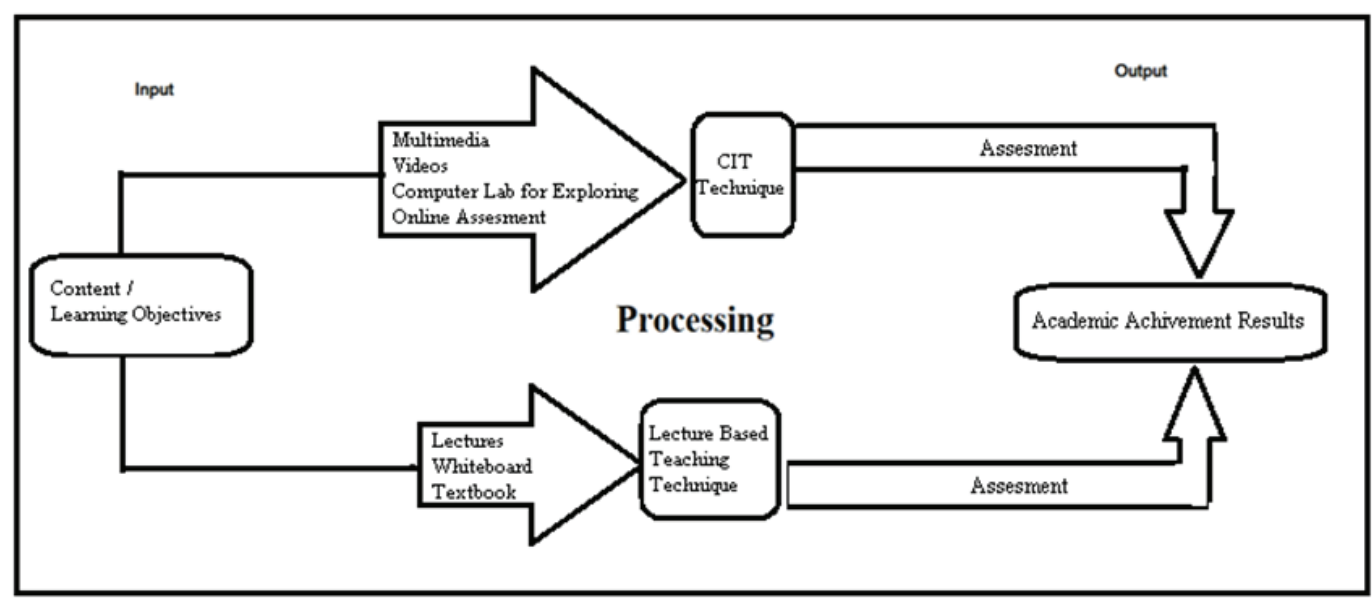

The conceptual framework (figure 1) displays a process where inputs are 
learning objectives for the students, which include the content, which has been kept as a constant for both the groups. The second step shows the processing of the input, which includes teaching methods, which have been considered as variables for both the groups. Group A is instructed via the CIT technique and group B is taught by the lecture-based method. The output of the process is represented in the form of students' academic achievement results.

\section{Methodology}

The study followed an explanatory sequential mixed methods research approach, a type of research. In this type of research, the quantitative data are collected and analyzed first, followed by the collection and analysis of qualitative data (Tashakkori \& Teddlie 2010). In this method, qualitative data are used to support the findings of the quantitative data. Creswell and Creswell (2018) state that "sequential explanatory design is typically used to explain and interpret quantitative results by collecting and analyzing follow-up qualitative data" (p.211).

For the quantitative part of the study, the researchers used an experimental research strategy to investigate the research questions, as it is the most appropriate method to compare two different types of teaching strategies. According to Babbie (2015), experimental research is a study that follows a strategy that comprises hypotheses and variables that the researcher can work with. Collins and Feeney (2004) describe experimental researches as "studies where the researcher introduces interventions and studies the effects" (p.363). In an experimental study when nothing new has been introduced to group members, it is described as a control group and if an intervention has been introduced in a group, it is termed as the experimental group (Kothari, 2004). 


\section{Figure 2}

Variables of the Study

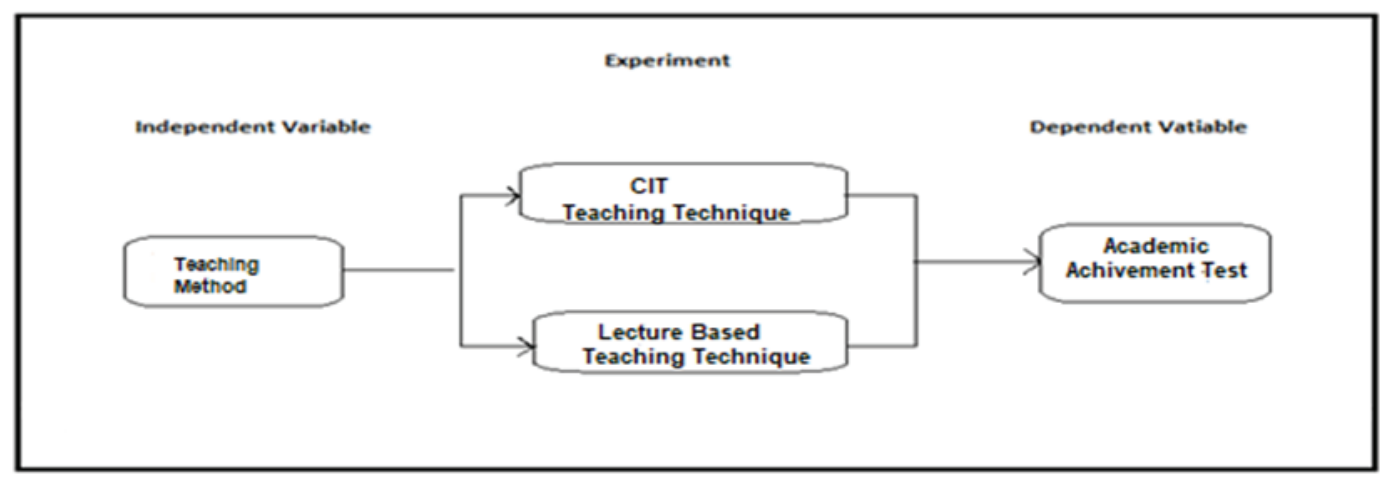

The variables of the study are displayed above in figure 2 , in the form of a chart where independent variables are teaching methods, which were not kept constant for both the groups. The figure also illustrates the experiment, where the researcher has used different teaching methods for the two groups. Further, it displays the dependent variable, which was used to check the effects of independent variables.

\section{Sample}

This study was conducted in private sector school X (pseudonym) which is officially registered as a high school. The researcher adopted a critical case sampling approach to select 62 students of grade 6 as the target population for the study. In critical case sampling, which is a type of purposive sampling, just one case is taken for the research because the researcher expects that studying a single set-up will disclose understandings that can apply to similar cases (Crossman, 2020). In this kind of sampling, participants are chosen following the aim of the study, anticipating that every participant will add to the value of the research by providing detailed information relevant to the study (Etikan et al., 2016). As the selected school was a boy's campus, the gender of all the participants was male and the average age of students was around 11 years. Participants were chosen from grade six because this is a transition stage for students after the successful completion of the first five years of study. 


\section{Research Instruments}

The instruments used to collect quantitative data included academic achievement tests and lab worksheets (practical). These instruments were developed to measure the academic achievement test results for both groups. Secondary data of students' examination scores before intervention were used as baseline test scores to check the academic achievement level of the students of each group. The data obtained were analyzed by using SPSS 22; an independent sample t-test was used to compare the means of academic achievement scores of both the groups.

Academic achievement tests were designed to check students' test scores in the theory and practice of science at grade six level. Achievement tests of 25 marks were designed from textbooks of physics, chemistry, and biology prescribed by the Cambridge curriculum for grade six, to check students' content knowledge. The achievement tests majorly included short answer questions, correction of incorrect statements, labeling, and drawing of diagrams and short definitions. To ensure validity, achievement tests were checked by experienced science teachers/ subject specialists before execution. The same tests were used for both experimental and control groups, after the completion of each chapter.

Regarding hands-on laboratory practical, the experimental group students were instructed via multimedia, whereby the teacher showed videos of professionals performing experiments and providing instructions to do so. On the other hand, the control group students were instructed by using blackboard and chart papers only. A lab worksheet comprising 25 marks was designed for the students of both groups to assess their practical performance skills while performing practical in the laboratory.

Triangulation in research is considered as a strategy used for enhancing the reliability and validity of the study and evaluation of the findings (Golafshani, 2003). To triangulate the collected data and for a deeper understanding of the research problems, Focus Group Discussions (FGD) were conducted with the students from both groups (A \& B). During the group interview sessions, the researcher acted as a moderator to facilitate the students so that a healthy interaction of participants could be maintained and to ensure that the discussion was to the point. The researcher audio recorded the responses and wrote notes when 
required. According to Stewart and Shamdasani (2014), "the main methods of data collection during a focus group discussion include audio and tape recording, note-taking and participant observation" (p.101).

Apart from choosing the correct methods for data collection, another aspect that particularly needs attention during a focus group meeting is its duration so that participants do not suffer from fatigue (Nyumba et al., 2018). The timing of the sessions might differ if the participants of the group are young, for example, school students, as they have a comparatively shorter attention span, and their focus and interest gets diverted earlier than adults (Gibson, 2012).

Two focus group sessions were conducted to examine students' perceptions regarding the integration of computer technology and the traditional method of teaching. Each session was 50 minutes' duration and a total of 16 students took part in both sessions, eight from group A and eight from group B.

\section{Compliance with Ethical Standards}

Ethical considerations were followed throughout the research study and all procedures required for collecting data were discussed with the principal and section head of the elementary section. The consent form included information regarding the confidentiality of the names of the participants and school and the use of pseudonyms to ensure anonymity. Moreover, because students participated in the focus group discussion, the section head signed consent on their behalf and acted 'in Loco Parentis' in school settings.

\section{Figure 3}

\section{Data Collection Procedure}

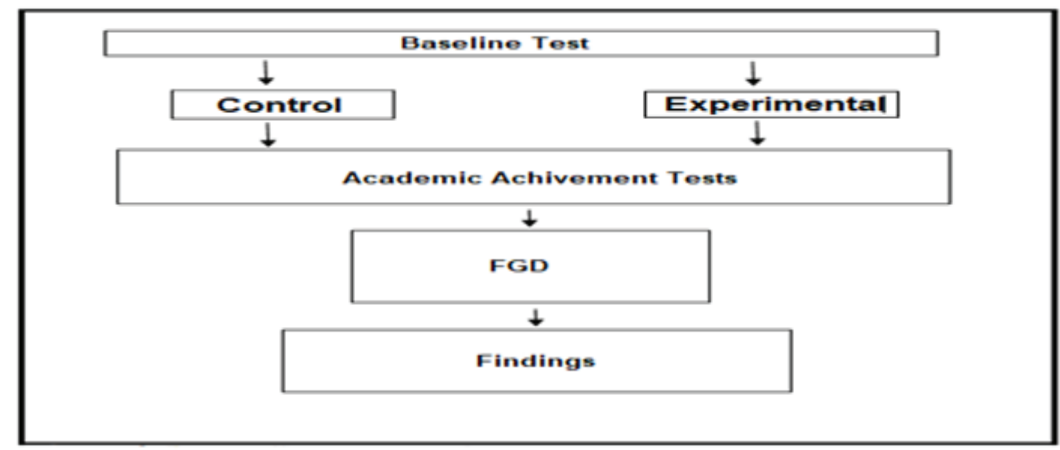


In figure 3, the baseline test is the first quantitative tool used to check the academic achievement level of all the students before the intervention. Control represents control group students, who did not experience any intervention program (lecture-based method), whereas experimental represents the experimental group students who experienced an intervention program (CIT). The academic achievement tests include theory and practical tests used to collect scores of both groups after the intervention program was delivered successfully to the experimental group. FGD represents Focus Group Discussion, the qualitative tool used to gather data regarding students' perceptions, which were used to support the findings of the quantitative data. The last column represents the findings of the study after the interpretation of both quantitative and qualitative data.

\section{Quantitative Analysis Findings}

Secondary data of last term's midterm examination scores for science subjects of grade six students were considered as baseline test scores. The purpose of gathering this secondary data was to identify if there was any significant difference in the mean scores of all selected grade 6 science students before grouping.

\section{Table 1}

Independent Sample Test

\begin{tabular}{|c|c|c|c|c|c|c|c|}
\hline \multicolumn{6}{|c|}{$\begin{array}{c}\text { Levene's Test for } \\
\text { Equality of Variances }\end{array}$} & \multicolumn{2}{|c|}{ t-test for Equality of Means } \\
\hline & & $\mathbf{F}$ & Sig. & $\mathbf{t}$ & df & $\begin{array}{l}\text { Sig. } \\
\text { (2-tailed) }\end{array}$ & $\begin{array}{c}\text { Mean } \\
\text { Difference }\end{array}$ \\
\hline \multirow{2}{*}{$\begin{array}{l}\text { GRAND } \\
\text { TOTAL }\end{array}$} & $\begin{array}{l}\text { Equal variances } \\
\text { assumed }\end{array}$ & .012 & .913 & -.548 & 60 & .586 & -3.129 \\
\hline & $\begin{array}{l}\text { Equal variances } \\
\text { not assumed }\end{array}$ & & & -.548 & 59.740 & .586 & -3.129 \\
\hline
\end{tabular}

Table 1 above shows the results of the independent sample t-test, according to Levene's Test for Equality of Variances shows F $(60)=.012$, sig value .913 which is higher than 0.05 , therefore equal variance assumed. The result of the t-test to compare mean scores of both the groups is $t(60)=-.54$, with a sig(2-tailed) value .59 which shows $\mathrm{p}>.05$ hence there is no significant difference in the mean scores 
of group 6A1 and 6A2 which shows that the achievement levels of the students in both groups are the same at this stage.

Three academic achievement tests were designed from three major branches of science, each of 25 marks for the students of both experimental and control groups, which were administered after the intervention program. A practical skill test (worksheet), comprising 25 marks was also designed to check the practical performance skills of the students from both groups which was administered in the laboratory after the intervention.

Cronbach Alpha test formula was used to check the reliability of achievement tests. Table 2 determines the reliability statistics of all test scores. Cronbach's Alpha test scores of 62 students for 15 items in the question paper is 0.811 , which is a highly reliable value and shows homogeneity in the test scores among the groups.

\section{Table 2}

Reliability Statistics

Cronbach's Alpha .811
$\mathrm{N}$ of Items

15

Table 3 shows the reliability statistics of Cronbach's Alpha test scores to measure the level of homogeneity in practical test scores of students within the groups, which shows good reliability of 0.78 , hence the data collected were reliable and appropriate for the study.

\section{Table 3}

Reliability Statistics

Cronbach's Alpha

.778
N of Items

4 


\section{Hypotheses Testing}

In this section, the analyzed results from gathered data were used to test each hypothesis of the study. The test used for every hypothesis and results obtained is mentioned by using tables.

\section{Hypothesis 1}

There is a significant difference in the overall performance of grade six students in science tests when taught by computer integrated teaching technique and when taught by lecture-based teaching method."

To check the overall performance of the students, the researcher used total marks which are based on scientific theory and practical performance test scores of students from both the experimental and control group. To find the difference in the overall performance of students taught by CIT and taught by traditional teaching technique, an independent sample t-test formula was applied by using SPSS version 22.

\section{Table 4}

Independent Samples Test

\begin{tabular}{|c|c|c|c|c|c|c|c|c|c|c|}
\hline \multicolumn{7}{|c|}{$\begin{array}{c}\text { Levene's Test for } \\
\text { Equality of Variances }\end{array}$} & \multicolumn{4}{|c|}{ t-test for Equality of Means } \\
\hline \multirow{4}{*}{$\begin{array}{l}\text { GRAND } \\
\text { TOTAL }\end{array}$} & & $\mathbf{F}$ & Sig. & $\mathbf{t}$ & df & $\begin{array}{c}\text { Sig. } \\
(2- \\
\text { tailed) }\end{array}$ & $\begin{array}{c}\text { Mean } \\
\text { Difference }\end{array}$ & $\begin{array}{c}\text { Std. } \\
\text { Error } \\
\text { Difference }\end{array}$ & $\begin{array}{r}95 \\
\text { Confi } \\
\text { Inte } \\
\text { of } \\
\text { Diffe }\end{array}$ & $\begin{array}{l}\text { \% } \\
\text { dence } \\
\text { rval } \\
\text { the } \\
\text { rence }\end{array}$ \\
\hline & & & & & & & & & Lower & Upper \\
\hline & $\begin{array}{l}\text { Equal } \\
\text { variances } \\
\text { assumed }\end{array}$ & 1.264 & .265 & 5.59 & 60 & .000 & 13.452 & 2.41 & 8.64 & 18.26 \\
\hline & $\begin{array}{l}\text { Equal } \\
\text { variances } \\
\text { not } \\
\text { assumed }\end{array}$ & & & 5.59 & 57.3 & .000 & 13.452 & 2.41 & 8.64 & 18.27 \\
\hline
\end{tabular}


In table 4, the sig value of Levene's Test for Equality of Variances is .265 which is greater than .05 hence equal variance assumed. The test showed a significant difference in the grand total scores of experimental and control group students, $\mathrm{t}(60)=5.59, \mathrm{p}<.005$, two-tailed with CIT $(\mathrm{M}=76.38, \mathrm{SD}=8.4)$ scoring higher than traditional $(\mathrm{M}=62.94, \mathrm{SD}=10.44)$ and the magnitude of difference in the means (mean difference $=13.5$ ). Therefore, it approves the first hypothesis that there is a significant difference in the overall performance of grade 6 students in science tests (theory and practical) when taught by computer integrated teaching technique and when taught by lecture-based teaching technique.

\section{Hypothesis 2}

There is a significant difference in science theory test scores of students taught via CIT compared to students taught by the lecture-based method.

\section{Table 5}

Independent Samples Test

\begin{tabular}{|c|c|c|c|c|c|c|c|c|c|c|}
\hline \multicolumn{7}{|c|}{$\begin{array}{c}\text { Levene's Test for } \\
\text { Equality of Variances }\end{array}$} & \multicolumn{4}{|c|}{ t-test for Equality of Means } \\
\hline & & $\mathbf{F}$ & Sig. & $\mathbf{t}$ & df & $\begin{array}{l}\text { Sig. } \\
(2- \\
\text { tailed) }\end{array}$ & $\begin{array}{c}\text { Mean } \\
\text { Difference }\end{array}$ & $\begin{array}{c}\text { Std. } \\
\text { Error } \\
\text { Difference }\end{array}$ & $\begin{array}{r}9 \\
\text { Conf } \\
\text { e Int } \\
\text { of } \\
\text { Diff }\end{array}$ & $\begin{array}{l}5 \% \\
\text { fidence } \\
\text { terval } \\
\text { f the } \\
\text { ference }\end{array}$ \\
\hline & & & & & & & & & Lower & Upper \\
\hline \multirow{2}{*}{$\begin{array}{l}\text { GRAND } \\
\text { TOTAL }\end{array}$} & $\begin{array}{l}\text { Equal } \\
\text { variances } \\
\text { assumed }\end{array}$ & 1.044 & .311 & 5.363 & 60 & .000 & 11.8709 & 2.21363 & 7.44304 & 16.2988 \\
\hline & $\begin{array}{l}\text { Equal } \\
\text { variances } \\
\text { not } \\
\text { assumed }\end{array}$ & & & 5.363 & 57.3 & .000 & 11.8709 & 2.21363 & 7.43873 & 16.3032 \\
\hline
\end{tabular}

Table 5 shows the results of the independent sample t-test, which is used to check if the difference between the test scores of the experimental and control group is significant or not. According to the t-test report, Levene's test for equality 
of variance shows a sig value of 0.31 which is greater than alpha value 0.05 , hence equal variance assumed. The t-test shows the highly significant difference in the test scores of experimental and control group students, $\mathrm{t}(60)=5.3$ and $\mathrm{p}<.05$, and the mean difference found is 11.87 . Hence the results of the t-test support the second hypothesis that there is a significant difference in academic achievement scores of science students.

\section{Table 6}

Independent Samples Test

\begin{tabular}{|c|c|c|c|c|c|c|c|c|c|c|}
\hline \multicolumn{7}{|c|}{$\begin{array}{c}\text { Levene's Test for } \\
\text { Equality of Variances }\end{array}$} & \multicolumn{4}{|c|}{ t-test for Equality of Means } \\
\hline & & $\mathbf{F}$ & Sig. & $\mathbf{t}$ & df & $\begin{array}{l}\text { Sig. } \\
(2- \\
\text { tailed })\end{array}$ & $\begin{array}{c}\text { Mean } \\
\text { Difference }\end{array}$ & $\begin{array}{c}\text { Std. } \\
\text { Error } \\
\text { Difference }\end{array}$ & $\begin{array}{r}95 \\
\text { Confic } \\
\text { Inte } \\
\text { of } t \\
\text { Diffe }\end{array}$ & $\begin{array}{l}\% \\
\text { dence } \\
\text { rval } \\
\text { the } \\
\text { rence }\end{array}$ \\
\hline & & & & & & & & & Lower & Upper \\
\hline \multirow{2}{*}{$\begin{array}{l}\text { GRAND } \\
\text { TOTAL }\end{array}$} & $\begin{array}{l}\text { Equal } \\
\text { variances } \\
\text { assumed }\end{array}$ & 5.827 & .019 & 2.351 & 60 & .022 & 1.581 & .672 & .2356 & 2.9257 \\
\hline & $\begin{array}{l}\text { Equal } \\
\text { variances } \\
\text { not } \\
\text { assumed }\end{array}$ & & & 2.351 & 46.15 & .023 & 1.581 & .672 & .2272 & 2.9340 \\
\hline
\end{tabular}

\section{Hypothesis 3}

There is a significant difference in science practical skills test scores of science students taught by CIT and lecture-based teaching methods.

The results of the independent sample test are given above in Table 6 . According to results, Levine's test for equality of variances represents a sig value of 0.019 which is less than .05 , therefore, equal variances not assumed and the considered $t$ value is $t(46)=2.35$ and $p<.05$ which shows a significant difference in the mean score of experimental and control group students practical performance 
tests scores, and accepts the third hypothesis. Further, the results revealed that the students' taught by computer integrated technology achieved significantly higher marks in practical performance skill tests than the students taught by the traditional teaching approach.

\section{Qualitative Data Analysis and Findings}

Software NVIVO 11 was used to organize qualitative data, generate patterns from the participants' responses, and develop themes. Figure 4 shows a model of pictorial presentation of the themes generated with the help of NVIVO 11.

\section{Figure 4}

Themes classification (NVIVO model)

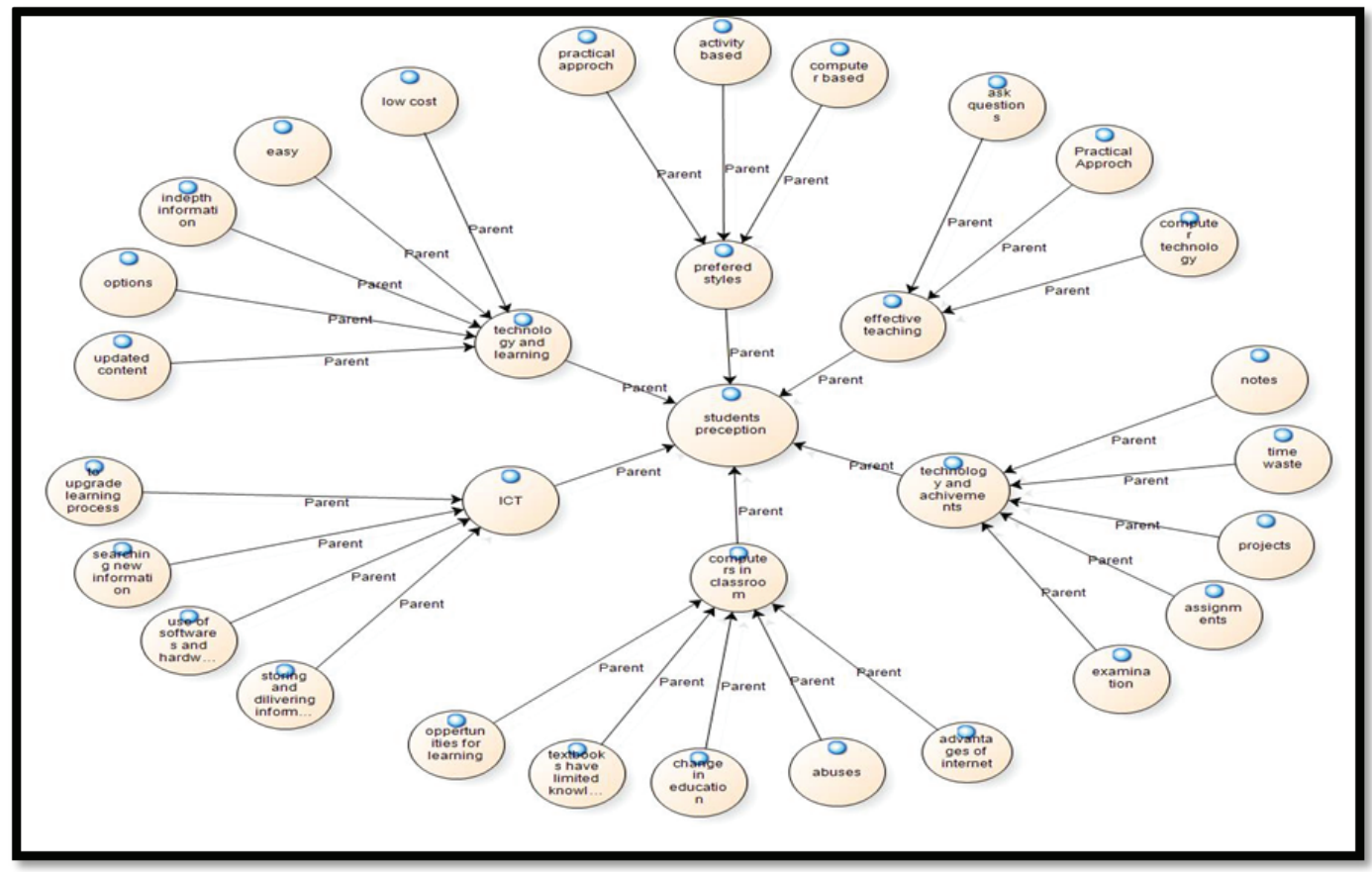

\section{Technology-Based Teaching}

Approximately $95 \%$ of students from both FGD sessions were not in favor of the lecture-based teaching method. Most of the students were in favor of introducing computer technology for learning purposes. 
Students from the control group were vociferous in advocating change in teaching routines; a student (Respondent H_F1) from the control group while responding in favor of computer technology said:

"To make classroom alive and to encourage active participation of students, it is essential for teachers to introduce something new in the classroom like some songs, videos, or photos connecting daily life and the topic under discussion."

Another participant responded C F1 commented:

"Teachers should use subject-related video clips and online games. These types of strategies help in increasing students 'interest in the subject.'

\section{Preferred Teaching Style for Learning Science}

Most responses from students of both groups favored the incorporation of computer technology for learning science; the following statements from interviewees highlighted the use of technology in teaching and learning science in classrooms.

(Respondent C F2):

"It is easy to understand when someone explains with the help of practical demonstrations like the use of video clips and other things on the internet."

(Respondent B F1):

"I consider the practical approach is a must for learning science; besides experiments in labs, the teacher can show videos related to that practice to make it even more clear to understand the concept."

(Respondent H F2):

"For teaching science in the classroom, I prefer for teachers to use the latest technology because science and technology are interrelated, so 
students will be aware of up-to-date knowledge as science is not constant and is continuously changing."

\section{Technology and Learning}

Participants were asked to define how computer technology and learning of science are related and to what extent technology has helped them in understanding science concepts and developing an interest in the subject. The following quotes from students showed how computer technology has helped them in learning science:

(Respondent A F1):

"Absolutely! it helps in understanding the concepts as computer technology provides an opportunity to learn through multiple sources like Google, YouTube, khan academy, and many more."

(Respondent E F1):

"Computer technology has multiple options like on the internet we have information present in audio, video, text, and animation. These options help in understanding the concepts of science and developing interest in the subject."

\section{Technology and Achievements}

To get information regarding the role of computer technology in achieving high scores, participants were asked to share whether computer technology in education has helped them in scoring good marks. Additionally, they were also asked to share if they have ever used technology for preparing assignments and projects for science subjects. Most interviewees from the experimental group shared that they took help from computer technology to prepare for the examination. Some of the views expressed by students are the following:

(Respondent A F2):

"Yes, because it helped in understanding the concepts, which ultimately 
assisted in solving the exam papers."

(Respondent E F1):

"Yes, if I am not able to understand any specific topic then I mostly ask my parents and they refer to the internet for a better and authentic explanation."

Another student, (Respondent E F1) commented:

"For projects and assignments, I use the internet as there is very limited information given in the textbook, most of which are related to theory. For creative and interesting work, I have to use computer technology."

Overall, the students from both groups approved of the integration of computer technology and considered it an effective tool for learning science and for scoring higher grades in tests. The enthusiasm of both groups demonstrated their will to adopt CIT in classrooms.

\section{Discussion}

The findings of the current study are aligned with research studies in the existing scholarly literature; even though most studies were conducted at the intermediate, graduate, and master level and in international contexts. The present research, therefore, attempted to bridge the gap in researching at the elementary level of education, particularly for integrating technology in science education at the elementary school level in Pakistan.

During the focus group discussion, the participants spoke about the change in teaching methodology, especially in science education. They were in favor of introducing computer technology in science instruction as it helps in making the classrooms come alive and motivates the students to learn. Scholarly literature also highlights the use of the internet for both students and teachers. Osborne and Hennessy (2003) indicate that authentic and updated information has now become the need and computer technology has the potential to deliver it easily to everyone at any time. The students underscored that the involvement of computer technology 
could upgrade the standard of science education.

The findings of the current research corroborate the findings of a study conducted by Khurshid et al., (2016), on the integration of technology in learning physics at the secondary school level in Pakistan. The findings of their study showed that the incorporation of technology increased students' interest and awareness of learning science.

Participants of the focus group discussion, particularly those from the experimental group, appreciated teaching techniques involving technology and predominantly preferred the use of video clips for teaching. They considered it as the reason for performing well and achieving good marks. The current study substantiates the findings of a study conducted by Gértrudix et al., (2017) in Russia on the use of video clips for teaching at the higher education level. This demonstrates that technology, particularly the use of video clips can be helpful, not only at the elementary school level but also in higher education scenarios.

Overall, the students from the experimental group and control group were in favor of using computer technology in classrooms. Students believed that they could understand science concepts better if the technology is involved, as they want to learn from daily life examples, which can be displayed in the form of images and videos. It provided them the facility to search and share information from anywhere anytime. They also considered it a useful tool for improving the academic achievement test scores in science.

\section{Conclusion and Recommendations}

To conclude, the academic performance of students is directly proportional to their level of interest in the subject and the process of learning. The experiment conducted for the study demonstrated that the students taught by the CIT technique scored significantly higher marks in science achievement tests than the students taught by the lecture method. In addition, technology acts as a powerful tool for understanding complex science concepts and contributes to developing students' interest in the subject. According to Tikam (2016), computer technology helps in enhancing a constructive approach in the teaching and learning process.

Quality of education is one of the glitches of Pakistan's education system, 
and the current study suggests that one aspect that could contribute to quality is the inclusion of computer technology in classrooms. Both quantitative and qualitative outcomes of the study demonstrate that CIT in education advances students' learning process by developing a curiosity for the subject, providing access to updated and unlimited information, and instigating the habits of inquiry-based learning.

Furthermore, the study sheds light on the inclusion of computer technology in delivering practical skills required for science laboratory work. Regular training in science practical helps students develop an understanding of science (Lunetta et al., 2007).

Overall, the findings of the study recommend school management, educators, and policymakers, to focus on this area of education. A positive change is required in the cognitive and psychomotor skills (required for science) under strong intervention programs where Information and Communication Technology can play a vital role in bridging the gap in providing access and quality of education in Pakistan.

\section{References}

Ahmed, S. M. (2016). The role of technology in Pakistani private schools [Master's thesis, University of Oxford] Oxford University.

Ali, S. (2018, February 1). The education crisis. Daily Times. http://www.dialytimes.com.pk/192796/the-education-crisis

Annual Status of Educational Report-ASER (2013, January 16). Annual status of education report: ASER-Pakistan

http://www.aserpakistan.org/document/aser/2013/reports/national/ASER National_Report_2013.pdf

Babbie, E. R. (2015). The practice of social research (14 ${ }^{\text {th }}$ Ed.). Cengage Learning US. http://www.world.org/title/practice-of-social-research/oclc/939265246

Cauthers, J., \& Cuathers, B. (2018, April 18ed). Technology integration in a 21st century science classroom. EdTechTeam.

http://edtechteam.com/blog/2018/04/technology-integration-in-a-21st-cent ury-science-classroom/

Collins, N. L., \& Feeney, B. C. (2004). Working models of attachment shape perceptions of social support: Evidence from experimental and 
observational studies. Journal of Personality and Social Psychology, 87(3), 363 -383. http://doi.10.1037/0022-3514.87.3.363

Creswell, J. W., \& Creswell, J. D. (2018). Research design: Qualitative, quantitative, and mixed methods approaches. Sage Publications.

Crossman, A. (2020, March 19). Understanding purposive sampling: An overview of its methods and applications. Thoughtco.

http://www.thoughtco.com/purposive-sampling-3026727

Deaudelin, D., \& Loiselle, J. (2006, November, 26-30). ICT implementation stages of primary school teachers: The practices and conceptions of teaching and learning. Australian Association for Research in Education National Conference, http://www.aare.edu.au/data/publication/2006/lef06578.pdf

Etikan, I., Musa, S. A., \& Alkassim, R. S. (2016). Comparison of convenience sampling and purposive sampling. American Journal of Theoretical and Applied Statistics, 5(1), 1-4. http://doi.10.11648/i.ajtas.20160501.11

Gértrudix, M., Rajas, M., Barrera, D., Bastida, M., \& Soto, C. (2017). Production of educational video: analysis of the audiovisual production of the URJCx MOOCs. Sierra, J., New audiovisual technologies for new digital interactive narratives in the multi-device era. McGraw Hill Education, 289-302.

Gibson, J. E. (2012). Interviews and focus groups with children: Methods that match children's developing competencies. Journal of Family Theory \& Review, 4(2), 148-159.

Golafshani, N. (2003). Understanding reliability and validity in qualitative research. The Qualitative Report, 8(4), 597-606.

http://nsuworks.nova.edu/tqr/vol/18/8/iss4/6

Harlen, W. (2017). The teaching of science in primary schools $\left(6^{\text {th }}\right.$ ed.). Routledge. Hofstein, A., Eilks, I., \& Bybee, R. (2011). Societal issues and their importance for contemporary science education - a pedagogical justification and the state-of-the-art in Israel, Germany, and the USA. International Journal of Science and Mathematics Education, 9(6), 1459-1483.

http://dx.doi.org/10.1007/s10763-010-9273-9

Hogarth, S., Bennett, J., Lubber, F., Campbell, B., \& Robinson, A. (2006). ICT in science teaching. EPPI-Centre. Social Science Research Unit, Institute of Education, University of London. http://www.eppi.ioe.ac.uk/cms/Portals

Khurshid, K., Shah, A. F., \& Reid, N. (2016). Information and communication technology in learning Physics at secondary school level in Pakistan. 
Bulletin of Education and Research, 38(2), 135-151. http://files.eric.ed.gov/fulltext/EJ1210305.pdf

Kothari, C. R. (2004). Research methodology: Methods and techniques (2nd ed.). New Age International Publishers.

Livingstone, S. (2012). Critical reflections on the benefits of ICT in education. Oxford Review of Education, 38(1), 9-24. https://doi.org10.1080/03054985.2011.577938

Lunetta, V. N., Hofstein, A., \& Clough, M. P. (2007). Learning and teaching in the school science laboratory: An analysis of research, theory, and practice. In N., Leaderman, \& S. Abel (Eds.). Handbook of Research on Science Education (pp.393-441). Lawrence Eralbaum. http://scepub.com/reference/8276

Naqvi, K. (2020, June 27). Online education exposes lack of technology in Pakistan. Weekly Technology Times. http://www.technologytimes.pk/2020/06/27/online-education-exposes-lack -of-technology-in-pakistan

Newton, L. R. (2000). Data-logging in practical science: Research and reality. International Journal of Science Education, 22(12), 1247-1259. http://doi.org/10.1080/095006900750036244

Nyumba, T., Wilson, K., Derrick, C. J., \& Mukherjee, N. (2018). The use of focus group discussion methodology: Insights from two decades of application in conservation. Methods in Ecology and Evolution, 9(1), 20-32. http://doi.org/10.1111/2041-210X.12860

Osborne, J., \& Hennessy, S. (2003). Literature review in science education and the role of ICT: Promise, problems and future directions. Future Lab Series, Report 6. http://www.sciepub.com/reference/173927

Parker, C.E., Stylinski, C.D., Bonney, C.R., Delisi, J., Wong, J., Doty, C. (2019). Measuring quality technology integration in science classrooms. Journal of Science and Technology, 28(5), 567-578. http://doi.org/10.1007/s10956-019-09787-7

Park, H., Khan S., \& Stephen, P. (2009). ICT in science education: A quasi-experimental study of achievement, attitudes toward science, and career aspirations of Korean middle school students. International Journal of Science Education, 31(8), 993-1012.

http://doi.org/10.1080/09500690701787891

Riaz, N., \& Houlgate, M. (2019, February 16). Technology in the classroom. The News. 
http://www.thenews.com.pk/print/432465-technology-in-the-(classroom Riaz, R. (2018, December 29). ICT, the new hope for Pakistan's education system. The Nation.

http://www.nation.com.pk/29-Dec-2018/ict-the-new-hope-for-pakistan-s-e ducation-system

Scott, J. (2009). Perceptions of feedback one year on: A comparative study of the views of first and second year biological sciences students. Bioscience Education, 13(1), 1-9. http://dx.doi.org/10.31.3108/beej.13.2

Stewart, D. W., \& Shamdasani, P. N. (2014). Focus groups: Theory and practice. Sage publications.

Sylvia Hogarth, J. B. (2006). ICT in Science Teaching. Technical report. University of London: Research Evidence in Education Library.

Tashakkori, A., \& Teddlie, C. (2010). Sage handbook of mixed methods in social \& behavioral research (2nd ed.). Sage.

Tikam, M. V. (2016). ICT integration in education: Potential and challenges. Human Development and Interaction in the Age of Ubiquitous Technology. http://doi.10.4018/978-1-5225-0556-3.ch002

Zhang, P., \& Aikman, S. (2007). Attitudes in ICT acceptance and use. In J.A. Jacko (Ed.), Human-Computer Interaction: Interaction design and usability (pp. 1021-1030). Springer. https://doi.org/10.1007/978-3-540-73105-4_112

\section{Citation of this Article:}

Ashiq, S., \& Zehra, H. (2020). Impact of computer integrated technique in Science education at elementary level: A study in Karachi. Journal of Education and Educational Development. 7(2), 328-350. 